\title{
SCHOOL-BASED MANAGEMENT FOR GENERATING IMPROVED LEARNING OUTCOMES OF ALL PUPILS BY IMPROVING GOOD TEACHING AND LEARNING PRACTICES
}

\author{
Suyata \\ Ahmad Dahlan University, Yogyakarta, Indonesia \\ suyata07@gmail.com
}

\begin{abstract}
Simply decreeing that government transferring authority power and responsibility and accountability education matters to school and community would be unlikely resulting in the improved school quality. Even good policies accompanied with good new structural arrangement of school organization would be unable to generate better teaching and learning practices in the classroom due to the complexity of the classroom life. Introduction school- based management (SBM) program in developing countries like Indonesia in terms of conceptualization, strategies and implementation requires learning on-side, broad-based partnership regular monitoring and support. All have to change, central province, district/ municipal, sub-district office and school and classroom and actors within all directed to objectives. SBM program belongs to a kind or variance of educational restructuring process has a limited power to alter the existing teaching and learning practices. Structural aspect has to be arranged with the cultural aspect to achieve an improving school quality. Good leadership should comes first followed by good management. School disparities should be considered in implementing the SBM specially schools with disadvantage conditions. No one SBM model would bring good result of all school, the contextual and historical background might play significant factor for successful the SBM implementation.
\end{abstract}

Keywords: school leadership, good teaching and learning, improved school

\section{INTRODUCTION}

Office holders of education want that all school should be good all teachers deliver good teaching and all students do good learning and provide with what Stromquist called it doing more of the same. Deep understanding of the existing educational problems at the recent era would be unlikely. A symptomatic solution turns out to be pervasive and being used regularly and the similar problem remain there and even getting more difficult. Sound theories and research-based information seem to be neglected. A good management information system consisting of school improvement action indicators does not exist. In case there exist research findings relevant to problems at hand there is no capability to bring them to practice. Too many solution policies relied on speculation, ideology, power, and self/ group interest without theories guiding them and no reflection following the results.

For long period in Indonesia the owner of education has been the government for public education and the private on. They request stakeholders to assume responsibility without authority; the government holding power of decision and the government, parents and community share the responsibility to succeed. As the central government own less and less resource, local government, parents and community have been requested to participate by giving them authority and responsibility.

The establishment of Board of education at the province and district/ municipal level and the School committee at the school level seems to give signal that school belongs to the whole community provides them with their rights as well as their voices and then request them to be responsible, Public awareness of this kind seems to be important for creating a broad- based partnership in education need for improving schools.

Reflecting on my experiences providing professional services to the government related to community participation issues especially to improve access to school and Improving education quality something importance being noticed. The following finding was based visit and case study to South Sumatra, Central Java, Yogyakarta, East Java [26].

1. Community participation practices were narrow in coverage.

2. They were adhocratic and incidental.

3. They were school based at the request of the school.

4. They were interest bargaining in nature.

5. The school requested parent to participate, generally in form money being used for physical construction and non parent participation was limited.

The individual school or schools in collaboration with other schools should develop work together to generate broad-based partnership with multiple stakeholders. Following the study my recommendation included simplifying the organization being introduced to the local settings with capacity building training, extension and social marketing program, networking and partnership for education development.

The formation of the Board of Education and the School Committee un-fortunatelly has been the same time the existence of the government project. Areas and schools with the project were eager to take part but not those without and no sustainable action was observed.

The policy for expanding the SBM model to take into account the lesson from piloting studies with reflection about the concept, the strategies, and the implementation actions. Targeted regions and schools to disseminate need to be thoroughly reviewed.

\section{SCHOOL-BASED MANAGEMENT DEFINITION}

Many terms related to SBM concept were used including school-based management, school- 
based governance, school self-management, and school site management [8] [9]. As formulated generally SBM mean that school use authority making decision about their management: the use of their human, materials and financial resources. SBM the transfer of decision making power on management issues to the school level [8]

Caldwell made distinction between SBM and school-based governance; the first refers to transfer authority to professional- principal and teachers; the second refers to the transfer authority to school boards. Hanson, sited in [3], SBM is the transfer of decision making authority, responsibility and task, from higher to lower organization level or between organizations. Accordingly Hanson proposed 3 types SBM deconcentration, delegation, and devolution. Devolution means the delegation turn to autonomy unit that can take action independently. It is turn out to be more than the delegation of authority.

More specific view of SBM could be found in Leithwood and Menzies [8] as concept of control arriving at four types, including administrative control, professional control, community control, and balanced control; the first recide in the principal, the second in teachers corps, the third in the community and parents, the last in the boards, parents and professional.

There is no ideal model of SBM as stated by Gamage; Gamage and Zajda, the model would be a matter of degree, no absolute model of SBM applicable anywhere. Developing one model of SBM being implemented to all school even within a country would found problematic.

\section{WHY DO MORE AND MORE COUNTRIES INTRODUCE SBM?}

Freeing school personnel away from bureaucratic decisions would be positive for running school and classroom to improve teaching and learning. School personnel would be able to perform their managerial problems. Those in favor SBM provide a number of reasons. [8] noted (1) more democratic; (2) more relevant to local agenda; (3) less bureaucratic/ faster decision making; (4) stronger accountability; (5) greater resource mobilization.

However, many more factors are needed for SBM gets work and the most importance would be support especially weak school. There are many other ingrediants including capacity building, empowerment, networking, broad-based partnership and so on.

\section{ASKING IMPACT SBM ON IMPROVED LEARNING OUTCOMES}

Analyzing SBM impact on students' improved outcomes turn out to be controvercial in arguing evidence. The pole range from negative to positive with those in the middle expecting SBM potential for generating good teaching and learning which in turn arriving at raising achievement.

Some argue that SBM relate no systematic to students achievement in case positive correlation observed inconsistence. Leithwood \& Manzies (1998) observed little conclusive impact SBM on achievement
Caldwell has been proponent of SBM as able to generate impact on students learning outcomes. High achievement will be obtained by principles of (1) choice and competition, (2) school autonomy and (3) school accountability. Transforming education will be the key: significant, systematic, and sustained change nas occurred resulting in improved outcomes for all students in all settings thus making a contributions to the social and economic well being of a nation [5]. Strong schools need autonomy for improvement while weak schools need not autonomy but support. Fullan and Watson argue the existing infrastructure support the most important in the success of SBM.

\section{CONCLUDING STATEMENT}

The challenge of SBM implementation are numerous and complex. Short piloting would be not enough to expand nation-wide even across immediate schools due to unavailable sound theories on teaching and learning, lacking of research-based information, broad partnership, proper capacity building, on-side school work professional development and proper school leadership.

\section{REFERENCE}

[1] Ayeni, A. J. \& Ibukun, W. O. 2010. A conceptual model for school-based management operation and quality assurance in Nigerian secondary schools. Journal of Education and Learning, 2(2), 36-43.

[2] Adams, D. 1988. Extending the educational planning discourses: Conceptual and paradigmatic explorations, Comparative Education Review, 32, 1, 400-415.

[3] Bandur, A. 2012. Decentralization and school-based management in Indonesia. Asia Pacific Journal of Education Development, 1 (1): 33-47.

[4] Boyett, J., \& Boyett, J. 1998. Guru guide: The best ideas of the top management thinkers. New York: John Wiley \& Sons, Inc.

[5] Caldwell, B. J. 2014. Impact of school autonomy on student achievement in $21^{\text {st }}$ century education: A review of the evidence.

[6] Darling-Hammond, L. 2009. Steady work: How Finland is building a strong teaching and learning system. VUE Summer 2009.

[7] Deal, T. E. \& Peterson, K. D. 1994. The leadership paradox: Balancing logic and artistry in schools. Saan Francisco: Jossey-Bass Publishers.

[8] DeGrauwe, A. 2004. School-based management $(S B M)$ : Does it improve quality? Background Paper Prepared for the Education for All: Global Monitoring Report, The Quality Imperative.

[9] Devereaux, J. 2012. Research: Devolution in education. http://epx,sag pegroup.com/content/12/3

[10] Gardner, H. 1995. Leading mind: An anatomy of leadership. New York: Basic Books.

[11] Gertler, P., Patrinos, H. A., \& Codino, M. R. 2007. Methodological issues in the evaluation of schoolbased management reform.

[12] Goodlad, J. I. 1984. A place called school: Prospective for the future. New York: McGraw-Hill Book Company.

[13] Goodlad, J. I. 1994. Educational renewal: Better teachers better schools. San Francisco: Jossey-Bass Publishers.

[14] Harris, A. 2002. School improvement: What's in it for schools? London \&New York: Routledge Falmer 
[15] Harrison, L. C., \& Huntington, S. P. (Eds.). 2000. Culture matters: How values shape human progress. New York: Basic Books.

[16] Heyward, M., Cannon, R. A. \& Sarjana. 2012. Implementing school-based management in Indonesia. NC, USA: RTI Press.

[17] Fullan, M. G. \& Stiegelbauer, S. 1991. The new meaning of educational change. New York: Columbia University Press

[18] Gelb, M. J. 1995. Thinking for a change: Discovering the power to create, communicate and lead. New York: Harmony Books.

[19] Kemendikbud. 2013. Panduan Nasional MBS SD: Panduan Pelaksanaan MBS di Sekolah Dasar. BUKU $I V$. Jakarta: Depdikbud, Dirjen Pendidikan Dasar, Direktorat Pembinaan Sekolah Dasar.

[20] Kotter, J. 1996. Leading change. Boston: Harvard Business School Press.

[21] LaRoque, N., \& Boyer, Ml. 2007. Decentralization and school management: Idea from abroad. Education Series. Montreal Economic Insitute

[22] Mortimor, P. 1988. School matters: The junior years. Great Britain: Beaumont House.

[23] Nilson, L. B. 2010. Teaching at its best: A research based resource for college instructors. $3^{\text {rd }}$. San Francisco: Joddey-Bass, A Wiley Imprint.

[24] Ouchi, W. G. 2009. The secret of TSL: The revolutionary discovery that raises school performance. New York: Simon \& Schuster.

[25] Reeves, D. B. 2010. Transforming professional development into student results. Alexandria, VA: ASCD.

[26] Suyata. 1997. Cummunity participation in school development: Access, demand, and school construction. Technical Report No.2. Jakarta: Central Program Coordination Unit (CPCU), Junior Secondary Education Project World Bank Loan No. 4042-IND and No. 4095-IND.

[27] Townsend, T. 2002. 20 years of ICSEI: The impact of School Effectiveness and School Improvement in school reform. In International handbook of school effectiveness and improvement. The Netherland: Springer.

[28] Tata kelola manajemen berbasis sekolah nerorientasi pelayanan public Seri Pembelajaran. Jakarta: USAIDKinerja, www.kinerja.or.id.

[29] Vernes, G., Karam, R., \& Marshall, J. H. 2012. Implementation school-based management in Indonesia. Santa Monica: RAND Education.

[30] Wylie, C. 2000. What can New Zealand learn from Edmonton? 